\title{
Cesarska epifania. Ernst H. Kantorowicz jako badacz bizantyńskiej teologii politycznej
}

Nazwisko Ernsta Hartwiga Kantorowicza rzadko kojarzone bywa z bizantynologią. Niemiecki mediewista znany jest z powstałej w Niemczech biografii Fryderyka II Hohenstaufa ${ }^{2}$, którą określono mianem „najbardziej ekscytującej biografii średniowiecznego władcy, jaka powstała w XX wieku"3, a także z napisanych w Stanach Zjednoczonych Dwóch ciat króla, monumentalnej panoramy średniowiecznej teologii politycznej. $\mathrm{W}$ obu dziełach wątki dotyczące Bizancjum należą do pobocznych. Wprost na temat Bizancjum Kantorowicz wypowiedział się raz artykułem poświęconym „feudalizmowi” w Cesarstwie Bizantyńskim, zastrzegając, że wypowiedź miała charakter konferencyjnego zagajenia i została opublikowana drukiem wyłącznie na życzenie organizatorów ${ }^{5}$.

Śledząc naukową biografię niemieckiego mediewisty, nie sposób jednak nie zauważyć, że przez całe życie intensywnie zajmował się dziejami bizantyńskiego Wschodu. Od momentu przybycia do Stanów Zjednoczonych w 1939 roku, w okresie pracy na Uniwersytecie Kalifornijskim w Berkeley brał udział w dorocznych posiedzeniach „Berkeley Colloquium Orientologicum”, na forum którego wygłaszał referaty o tematyce bizantyńskiej. Tytuły niektórych z nich są nam zna-

1 Dr Robert Pawlik, asystent w Katedrze Kultury XX i XXI wieku na Wydziale Nauk HumanistycznychUKSW; e-mail: r.pawlik@uksw.edu.pl; ORCID: 0000-0002-0728-4347.

2 E. Kantorowicz, Kaiser Friedrich der Zweite, Berlin 1927.

3 N. Cantor, The Inventing Middle Ages, New York 1991, s. 85.

4 E.H. Kantorowicz, The King's Two Bodies. A Study in Mediaeval Political Theology, Princeton 1957.

5 E.H. Kantorowicz, „Feudalism” in the Byzantine Empire, w: Feudalism in History, red. R. Coulborn, Princeton 1956, s. 151: „This essay, written down hastily [...]. It is at the editor's request that the essay is published". 
ne ${ }^{6}$. W maju 1950 roku, w momencie przełomowym dla swojej kariery uniwersyteckiej ${ }^{7}$, zainaugurował współpracę z „Byzantine Studies Center" w Dumbarton Oaks. Wraz z Andreasem Alföldim, Františekiem Dvornikiem, André Grabarem, oraz Hanem P. L'Orange'em wziął udział w konferencji „Cesarz i pałac"8. Od momentu podjęcia pracy w Instytucie Studiów Wyższych w Princeton w 1951 roku został regularnym uczestnikiem dorocznych bizantynologicznych sympozjów organizowanych przez ośrodek Dumbarton Oaks. I w tym wypadku znamy tytuły niektórych jego wystąpień ${ }^{2}$. Począwszy od 1956 roku, zaczął ogłaszać swe rozprawy na łamach „Dumbarton Oaks Papers”10. Trzecia z nich, Oriens Augusti - Lever du Roi, ukazała się już po śmierci historyka. Poprzedzona została adnotacją, że śmierć przerwała autorowi pracę nad studiami „Eastern and Western in the History of Late Classical and Medieval Ideas”. Obok opublikowanego „Oriens Augusti” miały one obejmować pięć kolejnych rozpraw: „Synthronos”, „Rzymskie monety i chrześcijańskie rytuały” „Epifania i koronacja”, „Karol Łysy i Natales Caesarum”, „Roma i węgiel"11. Łatwo zauważyć, że tytuły rozpraw

6 „Liturgia Illustrata” (1941); „The Reception of the Kyrios” (1943), „Epiphany and Coronation” (1944); „Synthronos: Throne Sharing with the Deity” (1945); „Roman Coins and Christian Rites” (1948); „Oriens Augusti” (1950). Por. Y. Malkiel, Ernst H. Kantorowicz, „Romance Philology” 18/1 (1964) s. 12-13; R.E. Lerner, Ernst Kantorowicz: A Life, Princeton 2017, s. 272, przyp. 27.

7 Odmowa podpisania wprowadzonej przez uniwersytet kalifornijski przysięgi lojalności - pisemnej deklaracji potwierdzającej, że nigdy nie należał do żadnej partii ani organizacji komunistycznej - kosztowała Kantorowicza utratę pracy. Por. E.H. Kantorowicz, The Fundamental Issue: Documents and Marginal Notes on the University of California Loyalty Oath, San Francisco 1950.

8 W 1950 roku A. Grabar przewodniczył sympozjum „Cesarz i pałac”. Por. H. Maguire, Andre Grabar (1896-1990), „Dumbarton Oaks Papers” 95 (1991) s. XIV.

9 W 1950 roku Kantorowicz wygłosił dwa wykłady: „Epiphany and Byzantine Coronation” oraz „Synthronos: Throne Sharing with the Deity”; 30 kwietnia 1954 roku w ramach sympozjum „Byzantine Liturgy and Music” wygłosił referat „,The Baptism of the Apostles”; 1 maja 1958 roku na sympozjum „The Dumbarton Oaks Collecition: Studies in Byzantine Art" mówił na temat „The Golden Marriage Belt and the Marriage Rings of the Dumbarton Oaks Collection".

10 E.H. Kantorowicz, The Baptism of the Apostles, „Dumbarton Oaks Papers”, 9-10 (1956) s. 204-251; E.H. Kantorowicz, On the Golden Marriage Belt and the Marriage Rings of the Dumbarton Oaks Collection, ,Dumbarton Oaks Papers” 14 (1960) s. 2-16. E.H. Kantorowicz, Oriens Augusti - Lever du Roi, „Dumbarton Oaks Papers” 17 (1963) s. 119-177.

11 Kantorowicz, Oriens Augusti - Lever du Roi, s. 118: „This article, which is based on a paper read at Dumbarton Oaks on April 5, 1951, was to have been the first of 
przygotowanych do druku zbieżne są z tytułami referatów wygłaszanych w latach czterdziestych na posiedzeniach „Berkeley Colloquium Orientologicum" oraz w latach pięćdziesiątych w ramach sympozjów organizowanych w Dumbarton Oaks.

Długotrwałe zainteresowanie Kantorowicza Cesarstwem Bizantyńskim podkreślił uczeń Kantorowicza, Ralph Giesey, który uznał „pięć nieogłoszonych studiów bizantyńskich" za najważniejszą część Kantorowiczowskich ineditów ${ }^{12}$. Dziesięć lat później owe poszukiwania Kantorowicza w obszarze późnej starożytności i Bizancjum krótko omówił Ihor Ševčenko ${ }^{13}$. W 2013 roku referat Kantorowicz i Bizantynologia wygłosił niemiecki bizantynolog Sergei Mariev ${ }^{14}$. Celem niniejszego artykułu nie będzie zatem kolejna próba prezentacji dorobku Kantorowicza na niwie bizantynologii, lecz wstępna ocena wkładu niemieckiego historyka do badań nad bizantyńską teologią polityczną. Chcę postawić pytanie, czy Kantorowicz, znany ze swych badań nad średniowieczną teologią polityczną, wniósł również wkład w zrozumienie teologii politycznej w Cesarstwie Bizantyńskim.

W swym opracowaniu oprę się na materiale źródłowym, którym są trzy rozprawy Kantorowicza ogłoszone na łamach Dubarton Oaks, oraz trzy z pięciu studiów bizantynologicznych, których manuskrypty, w różnym stopniu kompletności (niekiedy jedynie w formie wykładów), przechowywane są w bibliotekach Dumbarton Oaks oraz Instytytutu Leo

a series of «Studies Eastern and Western in the History of Late Classical and Mediaeval Ideas». The series was to have included the following additional titles: «Synthronos», «Roman Coins and Christian Rites», «Epiphany and Coronation», «Charles the Bald and the Natales Caesarum», «Roma and the Coal»". Wspomniany wykład nie został wygłoszony w ramach dorocznego sympozjum, które w 1951 roku miało miejsce w dniach 26-28 kwietnia i było poświęcone ikonoklazmowi.

12 R.E. Giesey, Ernst H. Kantorowicz Scholarly Triumphs and Academic Travails in Weimar Germany and the United States, ,Yearbook of the Leo Baeck Institute” 30 (1985) s. 201: „The five unpublished Byzantine studies, all of them in at least lecture form, constitute the most important part of Kantorowicz's scholarly Nachlass".

13 I. Ševčenko, Ernst H. Kantorowicz (1895-1963) on Late Antiquity and Byzantium w: Ernst Kantorowicz. Erträge der Doppeltagung Institute for Advanced Study, Princeton, Johann Wolfgang Goethe-Universität, Frankfurt, red. R. Benson - J. Fried, Stuttgart 1997, s. 274-287.

14 S. Mariev, Kantorowicz und die Byzantinistik referat w ramach konferencji „Mythen, Körper, Bilder: Ernst Kantorowicz zwischen Historismus, Emigration und Erneuerung der Geisteswissenschaften" zorganizowanej w dniach 4-6 września 2013 roku w Lüneburgu. Nie został on włączony do tomu pokonferencyjnego Mythen, Körper, Bilder: Ernst Kantorowicz zwischen Historismus, Emigration und Erneuerung der Geisteswissenschaften (red. L. Burkart, Göttingen 2015). 
Becka w Nowy Jorku, a obecnie zostały częściowo udostępnione w wersji cyfrowej ${ }^{15}$.

Założenie, że prace te można potraktować jako przyczynek do badań nad teologią polityczną w Cesarstwie Bizantyńskim, nie jest arbitralne. Sporządzony przez Kantorowicza wykaz publikacji, pochodzący z 1950 roku, tj. z czasów, gdy ubiegał się o stanowisko profesora w Institute of Advanced Studies w Princeton, w którego archiwum wykaz ten jest przechowywany, zawiera następującą adnotację: ,[Kantorowicz] is working on a book dealing with problems of medieval political theology, both in the Western world and in the Byzantine Empire; the chapters of the second volume of this work were read as papers by Kantorowicz at a Symposium of Byzantine scholars in Dumbarton Oaks, Washington, D.C., in Spring 1950"16. Autor pisze tu wprost, że obie prelekcje wygłoszone w ramach sympozjum w Dubarton Oaks (Syntrhonos: God and King as Thronesharers oraz Epiphany and Byzantine Coronation ${ }^{17}$ stanowią część przyszłej książki o teologii politycznej w Cesarstwie Bizantyńskim. Skoro Dwa ciała króla są ukoronowaniem badań nad teologią polityczną w świecie zachodnim, to z wielkim prawdopodobieństwem możemy przyjąć, że „Studies Eastern and Western in the History of Late Classical and Medieval Ideas" miały podsumowywać poszukiwania Kantorowicza w zakresie teologii politycznej w Cesarstwie Bizantyjskim.

15 Niepublikowane prace Kantorowicza, udostępnione w wersji elektronicznej, poprzedza następująca nota: E.H. Kantorowicz, Coronation Scenarios Eastern and Western, w: http:/www.archive.org/stream/ernstkantorowicz00reel01\#page/n994/mode/1up (11.01.2021): „Kantorowicz's last will and testament stipulated that none of his unpublished papers were to be published, for he did not think of any scholarly work as «his» until he had released it for publication. If, therefore, anyone chooses to cite this paper in print, the reference should be impersonal. Do not say „Kantorowicz says in such and such”, or „Kantorowicz believed [...]” but rather something like «the unpublished paper by Kantorowicz on [this or that] is useful for the problem of [such and such]»»".

16 „List of books and articles published by Ernst Kantorowicz”. Records of the Office of the Director: Faculty files: Box 18: Kantorowicz, Ernst, 1950-1967, w: The Shelby White and Leon Levy Archives Centre, Institute for Advanced Study, Princeton, NJ, USA, https:// albert.ias.edu/bitstream/handle/ 20.500.12111/2651/21658.pdf?sequence=1\&isAllowed=y (11.01.2021). Por. R.E. Lerner, Kantorowicz and Continuity, w: Ernst Kantorowicz. Erträge der Doppeltagung Institute for Advanced Study, Princeton, Johann Wolfgang GoetheUniversität, Frankfurt, red. R. Benson - J. Fried, Stuttgart 1997, s. 118, przyp.60.

17 Program konferencji „Cesarz i pałac”: https://www.doaks.org/research/byzantine/ scholarly-activities/the-emperor-and-the-palace/the-emperor-and-the-palace-program/at download/file (11.01.2021). 


\section{Teologia polityczna}

Zanim przejdę do zagadnienia teologii politycznej w Cesarstwie Bizantyńskim, należy ustalić, czym dla niemieckiego historyka była teologia polityczna jako taka. Już na początku lat czterdziestych stała się ona motywem przewodnim jego dociekań. W Laudes regiae. A Study in Liturgical Acclamation and Mediaeval Ruler Worship, książce opublikowanej w 1946 roku, lecz gotowej do druku blisko dziesięć lat wcześniej, Kantorowicz pisał o „karolińskiej teologii politycznej”" w 1952 roku artykuł Deus per naturam, deus per gratiam nosi podtytuł Nota na temat średniowiecznej teologii politycznej ${ }^{19}$. Podobnym podtytułem - Studium ze średniowiecznej teologii politycznej - opatrzone są Dwa ciała króla, a samo wyrażenie ,teologia polityczna” w pracy tej pojawia się kilkanaście razy. Po raz ostatni spotykamy je w artykule Oriens AugustiLever du roi ${ }^{20}$.

Choć często używana, kategoria ta nie została przez Kantorowicza nigdy zdefiniowana, ani nawet omówiona. Jedyna wskazówka, jaką znajdujemy, to krótki przypis w artykule Mysteries of State: An Absolutist Concept and Its Late Mediaeval Origins. Analizując popularne w dobie angielskiego absolutyzmu wyrażenie „misteria państwa”, Kantorowicz stwierdził, że wyrażenie to jest synonimem ,teologii politycznej”. W przypisie sprecyzował, że teologia polityczna to ,the expression, much discussed in Germany in the early $1930 \mathrm{~s}^{\prime 21}$. Wskazówka ta okazuje się cenna, gdyż pozwala wykluczyć szereg innych możliwych skojarzeń związanych z teologią polityczną 22 z których najbardziej znanym jest theologia politike (theologia civilis)

18 E.H. Kantorowicz, Laudes Regiae. A Study in Liturgical Acclamations and Mediaeval Ruler Worship, Berkeley - Los Angeles 1946, s. 59.

19 E.H. Kantorowicz, Deus per naturam, deus per gratiam: A note on Medieval Political Theology, „Harvard Theological Review” 45 (1952) s. 253-277.

20 E.H. Kantorowicz, Oriens Augusti - Lever du roi, „Dumbarton Oaks Papers” 17 (1963) s. 124, 130, 149.

21 E.H. Kantorowicz, Mysteries of State. An Absolutist Concept and its Late. Mediaeval Origins, „Harvard Theological Review” 48 (1955) s. 67, przyp. 6: „,The expression, much discussed in Germany in the early 1930s has become more popular in this country, unless I am mistaken, through a study by George LaPiana, «Political Theology», The Interpretation of History (Princeton, 1943)". Dodajmy, że artykuł G. LaPiany w tomie wydanym przez J.R. Strayera (The Intepretation of History, Princeton 1943, s. 151-186) nosi tytuł Theology of History i wyrażenie „teologia polityczna” nie pojawia się w nim ani razu.

$22 \mathrm{Z}$ bogatej literatury na temat pojęcia teologii politycznej, zob. m.in. H. Meier, Czym jest teologia polityczna? Wstepne uwagi na temat kontrowersyjnego pojęcia, 
ze słynnego trójpodziału teologii dokonanego przez Warrona, z którą św. Augustyn polemizował w O państwie Bożym ${ }^{23}$. W sformułowaniu ,wyrażenie często dyskutowane w Niemczech na początku lat trzydziestych" komentatorzy zgodnie widzą aluzję do sporu, jaki rozgorzał w Niemczech między jurystą Carlem Schmittem a teologiem i historykiem Kościoła Erikiem Petersonem ${ }^{24}$. Przedmiotem sporu była kwestia możliwości istnienia ortodoksyjnie chrześcijańskiej teologii politycznej.

t1. M. Kurkowska, „Teologia Polityczna” 1 (2003-2004) s. 177-184; E.-W. Böckenförde, Teoria polityki a teologia polityczna. Uwagi na temat ich wzajemnego stosunku, t1. M. Kurkowska, ,Teologia Polityczna” 3 (2005-2006) s. 301-309; M. Scattola, Teologia polityczna, tł. P. Borowski, Warszawa 2007; D. Sureau, Teologie polityczne XX wieku, tł. M. Grądzka-Holvoote, „Christianitas” 45-46 (2011) s. 111-140.

23 Warron wyróżnił trzy rodzaje teologii: „mityczną”, uprawianą przez poetów, której domeną był teatr; „teologię naturalną” filozofów, upatrujących w opowieściach o bogach alegorezy sił natury, oraz „teologię cywilną” czy obywatelską (theologia civilis), przez którą rozumiał rzymski kult państwowy odprawiany przez kapłanów i obywateli. Trójpodział ten znany jest głównie dzięki św. Augustynowi (De civitate Dei IV 27; VI 5-6; VI 12; VIII 1, tł. W. Kornatowski, Warszawa 1977). O tym, że „,teologia obywatelska” to synonim ,teologii politycznej”, informuje sam Augustyn (De civitate Dei VI 12): „Nunc propter tres theologias, quas Graeci dicunt mythicen physicen politicen, Latine autem dici possunt fabulosa naturalis civilis". Szerzej na temat trójpodziału Warrona, zob. J. Pépin, La „, Théologie tripartite” de Varron. Essai de reconstitution et recherche des sources, „Revue des études augustiniennes” 2 (1956) s. 265-294, G. Lieberg, The Theologia Tripartita as an Intellectual Model in Antiquity, w: Essays in Memory of Karl Kerényi, red. E.C. Polomé, Washington 1984, s. 91-115, J. Rüpke, Varro's tria genera theologiae: religious thinking in the late Republic, „Ordia prima” 4 (2005) s. 107-129.

24 Tak stwierdzenie to rozumieją m.in. G. Geréby, Carl Schmitt and Erik Peterson on the Problem of Political Theology: A Footnote to Kantorowicz w: Monotheistic Kingship: The Medieval Variants, Monotheistic Kingship: The Medieval Variants, red. J. Bak A. Al-Azmeh, Budapest, 2004, s. 33; D. Weber, Deus per naturam, deus per gratiam. Une note sur la theologie politique médiévale. Présentation, „Les Etudes philosophiques" 1 (2011) s. 105. Na temat sporu Schmitt-Peterson, zob. również: M. Nicoletti, Nowe spojrzenie na polemikę: Erik Peterson - Carl Schmitt, tł. T. Myśków - K. Marulewska, „44. Magazyn Apokaliptyczny” 4 (2012) s. 44-72. B. Nichtweiss, Apokaliptyczne teorie konstytucji. Carl Schmitt w kontekście teologii Erika Petersona, tł. K. Marulewska, „44. Magazyn Apokaliptyczny” 5 (2012) s. 179-216; R. Mehring, Nemo contra theologum nisi theologus ipse. Odpowiedź Carla Schmitta udzielona Erikowi Petersonowi, tł. K. Marulewska, „44. Magazyn Apokaliptyczny” 7 (2013) s. 114-132; R.J. Woźniak, Ontologia trynitarna i polityka. Uwagi na marginesie debaty Erika Petersona i Carla Schmitta o politycznej teologii, w: Rozwój dogmatu trynitarnego. Perspektywa historiozbawcza, red. A. Baron, Kraków 2015, s. 301-318; H. Maier, Erik Peterson i problem teologii politycznej, tł. K. Marulewska, „44. Magazyn Apokaliptyczny” 8 (2016) s. 201-220; J. Bartyzel, Nie-polityczna teologia Erika Petersona w: Chrześcijaństwo i Europa wo- 
W swym programowym dziele Teologia polityczna. Cztery rozdziały na temat suwerenności wydanym w 1922, ale wznowionym w 1934 roku $^{25}$, Schmitt bronił tezy, że wszystkie istotne pojęcia z zakresu nowożytnej teorii politycznej wywodzą się z zsekularyzowanych pojęć teologicznych oraz mają strukturę analogiczną do pojęć teologicznych ${ }^{26}$. Zajmując się głównie pojęciem suwerenności, niemiecki prawnik dowodził, że suwerenem jest ten, kto „decyduje o stanie wyjątkowym”, tj. kto ma prawo wprowadzać „Ausnahmezustand” i wydawać w nim decyzje ${ }^{27}$. Wbrew liberalnej tendencji do usuwania kategorii suwerenności na rzecz normy prawnej utrzymywał on, że kategorii tej wyeliminować się nie uda, gdyż nigdy nie uda się w pełni wyeliminować wyją̧tku. Zawsze bowiem przydarzyć się może sytuacja nadzwyczajna, której żadne zapisy prawa nie przewidywały. W ujęciu Schmitta istota suwerenności sprowadza się zatem do możliwości decyzji o wprowadzeniu stanu wyjątkowego, tj. o zawieszaniu obowiązywania prawa. Stan wyjątkowy jawi się tu zatem jako strukturalny odpowiednik cudu, przez który teologia rozumie zawieszenie obowiązywania praw przyrody. W rezultacie w teologii politycznej Schmitta suweren okazuje się politycznym analogonem wszechmocnego, stojącego ponad wszelkim prawem Boga.

Wniosek ten, powtórzony w 1934 roku tuż po dojściu do władzy Adolfa Hitlera, został odebrany jako instrumentalizowanie chrześcijaństwa i próba wprzęgnięcia teologii w legitymizowanie autorytarnego państwa. Na próbę tę ze szczególną mocą zareagował Erik Peterson. Niezwykle wyczulony na przemiany zachodzące $\mathrm{w}$ niemieckim chrześcijaństwie po $1933 \mathrm{roku}^{28}$ na dictum Schmitta odpowiedział traktatem Monoteizm jako problem polityczny. Swej polemice nadał charakter rozprawy historycznej, opatrując ją podtytułem Przyczynek do dziejów teologii politycznej w „Imperium

bec sekularyzacji. Religia w niemieckiej myśli politycznej XX wieku, red. A. Wielomski - Ł. Święcicki, Warszawa 2018, s. 93-113.

25 C. Schmitt, Politische Theologie - Vier Kapitel zur Lehre von der Souveränität, Berlin 1922 [Teologia polityczna. Cztery rozdziały poświęcone nauce o suwerenności, tł. M. Cichocki, w: Teologia polityczna i inne pisma, Kraków 2000, s. 33-83].

26 Schmitt, Teologia polityczna, s. 77: „Wszystkie istotne pojęcia z zakresu nowoczesnej nauki o państwie są zsekularyzowanymi pojęciami teologicznymi”.

27 Schmitt, Teologia polityczna, s. 45: „Suwerenny jest ten, kto decyduje o stanie wyjątkowym".

28 Por. E. Peterson, Die neueste Entwicklung der protestantischen Kirche in Deutschland, „Hochland” 31 (1933/34) s. 64-79 i 144-160 (przedruk w: E. Peterson, Theologie und Theologen, red. B. Nichtweiß, Ausgewählte Schriften 9/1, Würzburg 2009, s. 610-645). 
Romanum"29. Peterson dowodził w nim, że monoteizm zawsze miał wydźwięk wybitnie polityczny, a teologiczne pojęcie ,jednego Boga" powstało $\mathrm{z}$ transpozycji na grunt teologiczny politycznej koncepcji monarchicznego władcy. Odwrotnie niż Schmitt Peterson utrzymywał, że większość kluczowych pojęć teologicznych to „stranscendentalizowane” pojęcia polityczne. Wyobrażenie monoteistycznego Boga powstało na gruncie greckim, z projekcji wyobrażenia monarchy. Autor uchwycił ten proces z filologiczną precyzją, poddając analizie losy wyrażenia „boska monarchia”, które uważał za ekwiwalent nowożytnego pojęcia „monoteizm”.

Implicite pojęcie boskiej monarchii występuje już u Arystotelesa, który w XII księdze Metafizyki wprowadził koncepcję ,jednej zasady" (mia archē), do której zmierza cały wszechświat. Ontologiczny monarchizm Arystotelesa sprowadzał się zatem do przekonania, że tylko jeden może i powinien być panem wszystkiego ${ }^{30}$. Peterson podkreślał związek monarchizmu Arystotelesa z politycznymi ambicjami Aleksandra Macedońskiego, wychowanka Stagiryty. Nie przez przypadek koncepcja ,jednej zasady" pojawiła się w tym samym czasie, w którym macedoński król zaangażował się w zaprowadzenie jednego, wszechświatowego imperium. Innymi słowy, obraz monarchicznego kosmosu, wszechświata rządzonego przez jedną zasadę, wspierał w wymiarze metafizycznym dążenia polityczne do ustanowienia monarchii ziemskiej - systemu politycznego jednowładztwa. Zdaniem Petersona dyskurs monoteistyczny stale powracał w kontekście uniwersalistycznych aspiracji politycznych hellenistycznych królestw czy Cesarstwa Rzymskiego, dostarczając teologicznego usprawiedliwienia monarchii politycznej i obsadzając władcę w roli reprezentanta Boga. Skoro Bóg jest monarchą wszechświata, to reprezentujący go monarcha jawi się jako państwowe bóstwo. Innymi słowy, wyobrażenie jednego Boga usprawiedliwia władzę jednego cesarza w jednym cesarstwie.

W pseudo-Arystotelesowskim traktacie $O$ świecie pochodzącym najprawdopodobniej z III wieku przed Chrystusem Peterson znalazł jeszcze

29 E. Peterson, Der Monotheismus als politisches. Ein Beitrag zur Geschichte der politischen Theologie im Imperium Romanum, Leipzig 1935 [Monoteizm jako problem polityczny. Przyczynek do dziejów teologii politycznej $w$ imperium romanum, tł. J. Duraj „Res Publica Nowa” 20 (2012) s. 39-61]. Włączając „monoteizm” do opublikowanego po wojnie zbioru ,Theologische Traktate” (München 1951, s. 45-147), autor pominął podtytuł. Kantorowicz znał jednak wydanie z 1935 roku, które cytuje np. w Laudes regiae (s. 29, przyp. 50).

30 Aristotelis, Metaphysica XII, tł. K. Leśniak, Warszawa 1984. Por. Peterson, Monoteizm jako problem polityczny, s. 39-40. 
dosadniejsze sformułowanie analogii między monoteistycznym Bogiem i monarchiczną polityką ${ }^{31}$. Autor traktatu porównał Boga do perskiego „króla królów”, który ukryty w ogromnym pałacu roztacza panowanie nad swoim imperium za pośrednictwem armii urzędników (satrapów). Traktat De mundo dowodził, że możliwe jest harmonijne pogodzenie monoteizmu z dyskursem politeistycznym: na szczycie hierarchii bytów stał wprawdzie jeden, najwyższy, niewidoczny dla ludzkich oczu, Bóg-despota, jednak bezpośrednimi zarządcami świata były pomniejsze widzialne bóstwa, inteligencje, aniołowie, planety, satrapowie.

Peterson twierdził, że ten polityczny obraz Boga był obecny również w judaizmie. Filon z Aleksandrii, jako pierwszy w dostępnych nam źródłach, explicite posłużył się wyrażeniem ,boska monarchia"32. Czynił to jednak nie dla teologicznego wsparcia jednowładztwa scentralizowanego imperium, ale dla ugruntowania jedności narodu, w myśl formuły ,jeden Bóg - jeden naród".

Dyskursowi „boskiej monarchii” nie oparła się również teologia chrześcijańska. O boskiej monarchii pisał już Orygenes, jednak najdobitniej chrześcijańskiego Boga $\mathrm{w}$ kategoriach monarchicznych zinterpretował Euzebiusz. Tłumaczy, że o ile politeizm idzie w parze z poliarchią i anarchią, to wiara $\mathrm{w}$ jednego Boga istotowo związana jest $\mathrm{z}$ jednowładztwem, gdyż jednowładztwo odzwierciedla ustrój nieba. Cesarz rzymski swym panowaniem naśladuje „monarchię Boga” i układa swe ziemskie rządy zgodnie ze wzorem boskiego oryginału. Uzasadniając stworzone przez Konstantyna chrześcijańskie cesarstwo, biskup Cezarei twierdził ponadto, że chrześcijańska boska monarchia harmonijnie łączyła się z monarchią Imperium Romanum. Pokój, jaki zapanował w niebie dzięki zwycięstwu Chrystusa, łączy się z pokojem, który powstał wskutek zwycięstwa Konstantyna nad Licyniuszem, czyli wskutek ponownego zjednoczenia rzymskiego imperium i przywróceniem „władzy jednego”. Toteż jednemu królowi na ziemi odpowiada jeden Bóg - jeden Król w niebie i jeden królewski Logos ${ }^{33}$. Inaczej mówiąc, jak Chrystus jest zastępcą Boga-Króla

31 Arystotelis, De mundo 398a-398b, tł. A. Paciorek, Warszawa 1982. Por. Peterson, Monoteizm jako problem polityczny, s. 40-41.

32 Np. Philo, De Specialibus Legibus I 13-31, gdzie adaptuje on perypatetyckie wyobrażenie Boga jako monarchy kosmosu, Króla królów, porównując go do perskiego Wielkiego Króla. Cześć należy się wyłącznie najwyższej przyczynie wszechrzeczy, a nie „służbie i odźwiernym”, tj. bóstwom astralnym. Por. Peterson, Monoteizm jako problem polityczny, s. 41-42.

33 Por. Peterson, Der Monotheismus als politisches problem, s. 81 (tł. polskie s. 54). 
w niebie, tak chrześcijański cesarz jest zastępcą i naśladowcą ChrystusaKróla (Logosu) na ziemi.

Zdaniem Petersona biskup Cezarei zredukował chrześcijańskiego Boga do roli teologicznego wspornika cesarskiej monarchii: gwaranta jej pomyślności, czyli sprowadził chrześcijaństwo do funkcji, jaką pełniła rzymska religia państwowa. Z tego śmiertelnego zagrożenia chrześcijaństwo zostało wybawione przez rozstrzygnięcie dogmatyczne. Przyjęty w 325 roku na soborze nicejskim dogmat trynitarny wprowadził ortodoksyjny obraz chrześcijańskiego Boga jako współistotności trzech osób. Kategoria „,boskiej monarchii”, a także ariański subordynacjonizm podporządkowujący Syna Ojcu, jak i inne politycznie motywowane wizerunki Boga-jednowładcy, zostały w ten sposób odrzucone. Szczególną zasługę w przezwyciężeniu zagrożenia Peterson przypisał ojcom kapadockim, zwłaszcza Grzegorzowi z Nazjanzu, który podkreślał, że między Trójcą Świętą a rzeczywistością stworzoną nie zachodzi żadna odpowiedniośćç Innymi słowy, monarchiczny władca nigdy nie może uważać się za reprezentanta chrześcijańskiego Boga, a Trójcy Świętej nie można użyć jako narzędzia uprawomocnienia jednowładztwa. Podsumowując, Peterson twierdził, że dogmat trynitarny zlikwidował możliwość wszelkiej chrześcijańskiej teologii politycznej. Wniosek ten Peterson ujął następująco: „dokonało się fundamentalne zerwanie z wszelką «teologią polityczną», która «nadużywa chrześcijańskiego przesłania do usprawiedliwiania doraźnej sytuacji politycznej» ${ }^{35}$. W ostatnim przypisie Peterson odniósł się wprost do Carla Schmitta:

Według mej wiedzy pojęcie „teologii politycznej” wprowadził do literatury Carl Schmitt (zob. Politische Theologie, München 1922). Jego ówczesne krót-

34 Gregorius Nazianzenus, Oratio theol. III 2, w: Grzegorz z Nazjanzu, Mowy wybrane, Warszawa 1967, s. 313 (przekład zmieniony): „Trzy są najstarsze wyobrażenia o Bogu: anarchia, poliarchia, i monarchia. Pierwsze dwie zajmowały synów Grecji i niech nadal ich zajmują! Anarchia to bowiem w istocie bezład, zaś poliarchia to stan skłócenia, też zresztą prowadzący do anarchii i bezładu. Anarchia i poliarchia zmierzają zatem do tego samego, mianowicie do nieporządku, ten zaś - do rozkładu, bo bezład jest pierwszym stopniem rozkładu. My z kolei wyznajemy monarchię, lecz nie taką monarchię, gdzie władza ogranicza się do jednej osoby - bo może się zdarzyć, że nawet jedno, jeśli jest ze sobą w konflikcie (stasis), przechodzi w wielość. Natomiast na naszą monarchię składa się równość natury, zgodność myśli, tożsamość działania i spontaniczne dążenie jej części do jedności - czyli rzeczy, które sa niemożliwe dla stworzonej natury" (wyróżnienie - R.P.).

35 Peterson, Monoteizm jako problem polityczny, s. 58. 
kie rozważania nie miały jednak charakteru systematycznego. Dokonaliśmy tutaj próby udowodnienia na konkretnym przykładzie, że „teologia polityczna" jest niemożliwa z punktu widzenia teologii ${ }^{36}$.

W świetle chrześcijańskiego dogmatu trynitarnego teologia polityczna niemieckiego prawnika była odrzuceniem ortodoksji i regresem na pozycje ariańskie.

\section{Chrystologia polityczna}

W żadnej ze swych prac Kantorowicz nie odnosił się do Carla Schmitta, choć, jak łatwo wykazać, jego koncepcja musiała być mu znana przynajmniej za pośrednictwem Petersonowskiej polemiki ${ }^{37}$. Peterson natomiast należał do najczęściej przywoływanych przezeń autorów - Kantorowicz cytował m.in. Monoteizm jako problem polityczny, jak i szereg innych dzieł niemieckiego teologa ${ }^{38}$. Dlatego, gdy w konkluzji Dwóch ciat króla Kantorowicz stwierdził: „Notwithstanding, [...] some similarities with disconnected pagan concepts, the King's Two Bodies is an offshoot of Christian theological thought and consequently stands as a landmark of

36 Peterson, Der Monotheismus als politisches Problem, s. 158, przyp. 168 (tł. polskie s. 61 przyp. 101, przekład zmieniony).

37 O Kantorowiczu w kontekście teologii politycznej Carla Schmitta, zob. V. Kahn, Political Theology and Fiction in The King's Two Bodies, „Representations” 1 (2009) s. 77-101; J. Rust, Political Theologies of the Corpus Mysticum: Schmitt, Kantorowicz, and de Lubac w: Political Theology and Early Modernity, red. G. Hammill - J. Reinhard Lupton, Chicago 2012, s. 102-123; M. Herrero, On Political Theology: The Hidden Dialogue between C. Schmitt and Ernst H. Kantorowicz in The King's Two Bodies, „History of European Ideas” 41 (2015) s. 1164-1177; R. Pawlik, Le teologie politiche medievali e le loro ripercussioni novecentesche: Ernst Kantorowicz a confronto con Carl Schmitt e Erik Peterson w: Ernst Kantorowicz (1895-1963). Storia politica come scienza culturale, red. Th. Frank - D. Rando, Pavia 2015, s. 19-43.

38 Tytułem przykładu, w Laudes regiae, pracy o politycznym użytku z aklamacji liturgicznych, Kantorowicz obficie korzystał z ustaleń E. Petersona zawartych w Heis Theos. Epigraphische, Formgeschichtliche und Religionsgeschichtliche Untersuchungen, zur antiken ,Ein-Gott”-Akklamation (Göttingen 1926). W artykule The „King 's Advent”: And The Enigmatic Panels in the Doors of Santa Sabina (,The Art Bulletin” 4 (1944) s. 207-231) odwoływał się do opracowania E. Petersona (Die Einholung des Kyrios, „Zeitschrift für Systematische Theologie” 7 (1930) s. 682-702). Artykuł Kantorowicza wyrasta z wykładu konferencyjnego o petersonowskim tytule „Reception of the Kyrios”. Zob. R.E. Lerner, Ernst Kantorowicz. A Life, Princeton 2017, s. 272 przyp. 22. 
Christian political theology"39, to stwierdzenie to jawi się jako wyraźne zanegowanie Petersonowskiej tezy. Pomimo teologicznej niemożliwości chrześcijańska teologia polityczna była dla Kantorowicza faktem. W średniowieczu polegała jednak nie na ,monoteizmie politycznym” lecz ,politycznej chrystologii" ${ }^{40}$, nie na analogii między jednym Bogiem i jednym władcą, ale na rozumieniu chrześcijańskiego władcy w kategoriach ziemskiego obrazu Chrystusa.

Już w pracy na temat aklamacji „laudes regiae”, gdzie w tradycyjny porządek wezwań litanijnych do wszystkich świętych wprowadzone zostały imiona monarchów, a ciąg wezwań przerywano refrenem „Christus vincit, Christus regnat, Christus imperat”, Kantorowicz pokazał, że w epoce pokarolińskiej i ottońskiej obowiązywał chrystologiczny model teologii politycznej ${ }^{41}$. W litanii tej, śpiewanej podczas ceremonii koronacyjnych cesarzy i królów, dostrzegł manifestację przekonania, że Chrystus-król sprawuje władzę nad światem za pośrednictwem ziemskiego monarchy. Władza polityczna oznaczała władzę samego Chrystusa, którego ziemskim pełnomocnikiem jest cesarz.

Szerzej koncepcję tę Kantorowicz omówił w Dwóch ciałach króla ${ }^{42}$. Wyjaśnił w niej, że fundamentem chrystocentrycznej teologii politycznej był wzorowany na modelu biblijnym liturgiczny ceremoniał namaszczenia. Przed koronacją monarcha otrzymywał namaszczenie krzyżmem, zakładał kapłańskie szaty i pierścień. Przez ten rytuał spływała na niego specjalna łaska upodabniająca go do Chrystusa króla i kapłana oraz godność ,„pomazańca Pańskiego" (Christus Domini), ziemskiego obrazu Chrystusa per gratiam ${ }^{43}$.

Chrystologiczny typ teologii politycznej wyczerpał się w XII stuleciu wraz z reformą gregoriańską i sporem o inwestyturę. Kościół zakwestionował wówczas wyobrażenie króla-kapłana i odmówił namaszczania krzyżmem głowy monarchy, zaprzestał ubierania go w szaty kapłańskie oraz wkładania pierścienia. Pozbawione sakralnej sankcji cesarstwo zmuszone

39 Kantorowicz, The King's Two Bodies, s. 506. (tł. polskie, s. 399).

40 Na temat chrystologii politycznej, zob. Kantorowicz, Deus per naturam, deus per gratiam, s. 253; Kantorowicz, The King's Two Bodies, s. 159 (tł. polskie s. 130). Wyrażenie „chrystologia polityczna” pojawia się również u C. Schmitta (Theologische Theologie II. Die Legende von der Erledigung jeder Politischen Theologie, Berlin 1970, s. 11 [Teologia polityczna II, tł. B. Baran, Warszawa 2014, s. 15]).

41 Kantorowicz, Laudes regiae, s. 59.

42 Kantorowicz, The King 's Two Bodies, s. 42-86 (rozdział Christ-centered Kingship) (tł. polskie, s. 36-71).

43 Kantorowicz, Deus per naturam, Deus per gratiam, s. 253. 
zostało do wynalezienia nowego rodzaju teologii politycznej. Została ona stworzona przez prawników cesarskich w oparciu o odrodzone po stuleciach prawo rzymskie. W kodeksie Justyniana dostrzeżono teorię władzy cesarskiej legitymizowanej i uświęconej nie przez łaskę, lecz przez prawo. Cesarz był rozumiany teraz jako ,ucieleśnienie prawa” (nomos empsychos, lex animata). Jako „Żywe Prawo” oraz „Ojciec i Syn Sprawiedliwości” był on jedynym ,źródłem” prawa, to znaczy jego stanowienie było wyłączną prerogatywą cesarską. W rezultacie z namiestnika Chrystusowego stał się reprezentantem boskiej sprawiedliwości (vicarius Iustitiae) ${ }^{44}$. Kantorowicz podkreślał, że w nowej koncepcji cesarz zachował nawet status kapłański, lecz kapłaństwo to wynikało z faktu, że prawo rzymskie nazywało prawników „kapłanami sprawiedliwości” (Iustitiae sacerdotes) ${ }^{45}$.

Ten nowy rodzaj legitymizacji władzy politycznej Kantorowicz nazywał „,nomocentrycznym” (law-centered kingship) ${ }^{46}$, a niekiedy również „świecką teologią polityczną"47. Niemniej rezydua chrystologicznego charakteru władzy politycznej nadal pozostały. Historyk dostrzegał je m.in. w wyobrażeniu ,zdwojenia” osoby władcy, którego późnym przykładem była teoria „dwóch ciał króla”. Dla wyjaśnienia ciągłości dynastycznej prawnicy epoki tudorowskiej odróżniali fizyczną osobę króla od „urzędu” króla. W tym celu np. Plowden (1518-1585) posłużył się fikcją prawną, wedle której król ma dwa ciała: śmiertelne ciało fizyczne (body natural) oraz nieśmiertelne ciało polityczne (body politic). W rozumieniu angielskiego prawnika politycznym, tj. zbiorowym ciałem króla było państwo. Ciało to nigdy nie umiera, lecz po śmierci władcy przechodzi na ciało naturalne sukcesora. Koncepcja dwóch ciał króla, pomimo wszystkich możliwych analogii w tradycji grecko-rzymskiego antyku, była zdaniem Kantorowicza pochodną chrześcijańskiej nauki o dwóch naturach Chrystusa oraz o Kościele jako mistycznym Jego ciele. Można ją zatem było uznać za „kamień milowy w dziejach chrześcijańskiej teologii politycznej" 48 .

44 Kantorowicz, The King's Two Bodies, s. 191 (tł. polskie, s. 155).

45 Kantorowicz, The King's Two Bodies, s. 117-125 (tł. polskie s. 95-102).

46 Kantorowicz, The King's Two Bodies, s. 87-192 (rozdział Law-Centered Kingship) (tł. polskie s. 72-156).

47 Kantorowicz zauważa (The Kings Two Bodies, s. 87, tł. polskie, s. 72): „, The king a gemina persona, human by nature and divine by grace: this was the high-mediaeval equivalent of the later version of the King's Two Bodies, and also its foreshadowing. Political theology in that early period was still hedged by the general framework of liturgical language and theological thought, since a Church-independent secular political theology [podkreślenie - R.P.] was as yet undeveloped".

48 Kantorowicz, The Kings Two Bodies, s. 506 (tł. polskie, s. 399). 
Podsumowując, o ile dla Petersona teologia polityczna wiązała się z monarchicznym wyobrażeniem Boga obliczonym na usprawiedliwienie jednowładztwa, o tyle dla Kantorowicza oznaczała ona chrystologiczne uprawomocnienie i sakralizację władcy. W jednym przypadku chodziło zatem o „monarchizację” Boga, w drugim - o ,chrystyzację” cesarza. O ile przedstawianie Boga na wzór monarchy mogło być uznane za niezgodne $\mathrm{z}$ ortodoksją, o tyle wyobrażenie władcy jako obrazu Chrystusa było - zdaniem Kantorowicza - autentycznie chrześcijańską formą teologii politycznej.

\section{Polityczna chrystologia w Cesarstwie Bizantyńskim}

Czym jednak byłaby teologia polityczna w Cesarstwie Bizantyńskim? Ponieważ Bizancjum nie doświadczyło „papieskiej rewolucji”, której skutkiem była desakralizacja i odkościelnienie cesarza, możemy bezpiecznie założyć, że mówiąc o tamtejszej teologii politycznej, Kantorowicz miał na myśli chrystocentryczny model panowania. W istocie cesarska „chrystomimeza" jawi się jako motyw przewodni większości bizantyńskich prac Kantorowicza. Prześledźmy to na kilku przykładach.

Pierwszy wykład, wygłoszony w ramach sympozjum w Dumbarton Oaks w 1950 roku, zatytułowany został Epiphany and Byzantine Coronation $^{49}$. Kantorowicz odniósł się w nim do toczącego się wśród bizantynologów sporu o to, czy ceremoniał koronacyjny miał charakter kościelny czy raczej prawno-państwowy. Zdaniem historyka kontrowersja wynikła z niedostatecznego uwzględnienia rytualno-liturgicznego aspektu zagadnienia. Toteż sam zaproponował analizę bizantyńskiej koronacji w perspektywie liturgicznej zgodnie z założeniem, któremu hołdował również w wielu innych swych pracach, a mianowicie że liturgia stanowi kluczowy materiał źródłowy do badań nad politycznym imaginarium średniowiecza. Punktem wyjścia jest konstatacja, że modelem dla cesarskiej koronacji był Stary Testament, zwłaszcza opis koronacji Dawida przez Samuela. Przy bliższym przyjrzeniu się koronacyjne formuły liturgiczne wykazywały pokrewieństwo z rytuałem chrzcielnym i odwrotnie - chrzest, w kategoriach teologicznych, był rozumiany jako nadanie ochrzczonemu godności królewskiej. W tym kontekście Kantorowicz podkreślił, że Kościół Wschodni wspomina liturgicznie chrzest Chrystusa w Jordanie świętem Epifanii, wi-

49 E. Kantorowicz, Epiphany and Byzantine Coronation - wykład wygłoszony 28 kwietnia 1950 r. w ramach sympozjum „The Emperor and the Palace”, w: http://www. archive.org/stream/ernstkantorowicz00reel01\# page/n991/mode/1up (11.01.2021). 
dząc w nim pamiątkę ukazania się światu Syna Bożego. Następnie autor omówił rolę bizantyńskiego cesarza w obchodach tego święta, za jej emblematyczny wyraz uznając prokypsis - ceremonię dorocznego ukazywania się cesarza w dniu 6 stycznia na podwyższeniu zbudowanym na dziedzińcu pałacu w Blacharnach. Opierając się o De officialibus Pseudo-Kodinosa, Kantorowicz opisał tę uroczystość następująco:

Prokypsis $[\ldots]$ z czasem zaczęło oznaczać zarówno ceremonię, jak i specjalny rodzaj platformy na podwyższeniu. Prokypsis było zatem drewnianą estradą, wzniesioną na wolnym powietrzu, udekorowaną, jak się wydaje, tapiseriami oraz złotą kurtyną. Gdy cesarz wraz z Caesears i Augustae wchodził na estradę tylnymi schodami, kurtyna z przodu była zasłonięta. Przed prokypsis gromadził się dwór, kler, przedstawiciele wojska i lud oczekujący na pojawienie się władców. Następnie, gdy członkowie rodziny cesarskiej zajęli stosowne miejsca na estradzie, kurtynę odsłaniano: oczom zgromadzonych ukazywali się cesarze widoczni od kolan wzwyż. Ilekroć ceremonia odbywała się po zmroku, a tak z reguły bywało, scenę oświetlało sztuczne światło. W mroku nocy prokypsis sprawiała wrażenie wyspy światła, w blasku którego lśnił numen praesens - objawiał się bazyleus, dokonywała się cesarska epifania ${ }^{50}$.

Uroczystość Objawienia Pańskiego była zatem świętowana „cesarską epifanią": ukazaniem się świetlistej postaci cesarza w koronie na głowie, w błyszczących szatach, oświetlonego blaskiem pochodni ${ }^{51}$. Kantorowicz twierdził, że w tym teatralnym geście cesarz zjawiał się jako numen praesens. Określenie to wydaje się dwuznaczne, z jednej strony sugeruje, że ceremonia prokypsis nawiązywała do pierwotnej idei epifanii, pełnej światła cielesnej manifestacji bóstwa. $Z$ drugiej daje do zrozumienia, że w dniu święta Objawienia Pańskiego w osobie bazyleusa oczom zgromadzonych ukazywał się Chrystus. Ów paralelizm cesarza i Chrystusa potwierdzały towarzyszące rytuałowi pieśni i aklamacje. Krótko mówiąc, rolą bazyleusa w dniu Epifanii było „reprezentowanie” Syna Bożego.

W artykule Oriens Augusti - Lever du Roi Kantorowicz podjął temat „cesarskiej teologii solarnej” ${ }^{2}$, śledząc jej rozwój od czasów późnego cesar-

50 Cytat według: Kantorowicz, Oriens Augusti-Lever du Rois, s. 158. Opis ten tylko nieznacznie różni się od wersji zamieszczonej w „Epiphany and Byzantine Coronation”.

$51 \mathrm{Na}$ temat ceremonii prokypsis, zob. M. Jeffreys, The Comnenian Prokypsis, „Parergon” 5 (1987) s. 38-53; R. Macrides, Pałac późnobizantyński i jego ceremoniat, tł. M. Biedrawa-Raczyńska, „Przegląd Nauk Historycznych” 1 (2014) s. 5-22.

52 Kantorowicz, Oriens Augusti-Lever du Roi, s. 131. 
stwa, kiedy to rzymscy imperatorzy coraz wyraźniej zaczęli utożsamiać się z bogami, zwłaszcza Heliosem. Ten typ późno antycznej teologii politycznej zasadzał się na „strange co-equality of rulers and light" ${ }^{53}$ : cesarz panował na ziemi na wzór słońca władającego niebem. Wyobrażenie to pozostało żywe aż do czasów Ludwika XIV, a nawet Napoleona. Kantorowicz ograniczył się do omówienia jednego aspektu tej teologii, a mianowicie motywu „wschodu” czy „wzejścia” cesarza (oriens augusti). Przekonanie, że monarcha „wschodzi wraz ze słońcem”, pojawiło się w Rzymie w III wieku, lecz znacznie wcześniej było już aksjomatem u Persów ${ }^{54}$. Tak jak słońce samym swym wzejściem odnosi zwycięstwo nad mrokami nocy, tak „niezwyciężony" monarcha swoją obecnością pokonuje wrogów cesarstwa.

Solarna teologia polityczna późnego cesarstwa nie była zatem rzymskim wynalazkiem, lecz została zapożyczona z bliskowschodnich kultów solarnych. Z tego samego źródła wywodziły się solarne metafory występujące w Starym Testamencie. W Nowym Testamencie - w Kantyku Zachariasza (Łk 1,78) - pojawia się proroctwo o mającym nadejść z wysoka „wschodzącym Słońcu”. W tej zapowiedzi objawienia się Boga imieniem Oriens Kantorowicz dostrzegł istotną modyfikację wcześniejszych wyobrażeń: „Czym innym jest porównywać bóstwo do słońca czy wschodu, a czym innym wyodrębnić «Wschód» i używać jako imienia bóstwa czy bosko-ludzkiego zbawcy. Oriens, jako imię, znacząco wykracza poza zwykłe porównanie czy metaforę" 55 .

Kantyk Zachariasza, a także słowa proroka Malachiasza „Dla was zaś, którzy żyjecie w bojaźni mego Imienia, zajaśnieje słońce sprawiedliwości” $(4,2)$ to loci classici powstałej w IV wieku chrześcijańskiej teologii solarnej, w której Oriens, „prawdziwe Słońce” oraz „Słońce sprawiedliwości” złączyły się w osobie Chrystusa. Przez Oriens chrześcijanie rozumieli zarówno narodziny (tj. wcielenie), chrzest (objawienie) jak i zmartwychwstanie Chrystusa.

Z punktu widzenia teologii politycznej nie był to moment błahy, gdyż właśnie kategorie solarne (cesarza-słońce oraz Chrystusa-Heliosa) okazały się wspólnym mianownikiem ułatwiającym połączenie rzymskiej monarchii z chrześcijańskim monoteizmem. Solarny monoteizm Aureliana i Konstantyna - dwóch cesarzy reformatorów, którzy przeobrazili religię rzymską w oparciu o kult słońca - znalazł kontynuację w solarnym charakterze chrześcijańskiego Boga i chrześcijańskich władców. Zdaniem

\footnotetext{
53 Por. Kantorowicz, Oriens Augusti - Lever du Roi, s. 131.

54 Por. Kantorowicz, Oriens Augusti - Lever du Roi, s. 131-132.

55 Kantorowicz, Oriens Augusti-Lever du Roi, s. 136.
} 
Kantorowicza jest „mało prawdopodobne, żeby pogańska idea «solarnego panowania» ziemskiego cesarza przetrwała w tak pełnej i niezakłóconej postaci, jak to miało miejsce w Bizancjum, gdyby nie usprawiedliwiało jej «solarne panowanie» władcy nieba i jego paralelizm z władcą ziemskim"56. Innymi słowy, obraz Chrystusa jako solarnego władcy wszechświata wspierał i legitymizował solarne panowanie bazyleusa jako Jego ziemskiego odzwierciedlenia.

Rzecz jasna, pogański polityczny kult słońca uległ w Bizancjum chrystianizacji. W tysiącletniej historii Bizancjum oba wątki, rzymska koncepcja oriens augusti oraz chrześcijańskie wyobrażenie oriens ex alto, zaczęły się przenikać. Zatem solarne panowanie bizantyńskich cesarzy było „nie tylko reliktem hellenistyczno-rzymskiej tradycji, ale także odzwierciedlało solarne panowanie chrześcijańskiego Boga" ${ }^{57}$. Niemniej, jak podkreśla Kantorowicz, oba nurty wiodły również osobne życie: „Tradycja hellenistyczna przetrwała przede wszystkim w kręgach dworskich litterati: poetów i mówców. Wpływy chrześcijańskie wyczuwało się głównie w sferze «cesarskiej liturgii», obchodach uroczystości dworskich i świąt roku kościelnego" 58 .

W świetle tej konstatacji należącą do sfery „,cesarskiej liturgii” ceremonię prokypsis Kantorowicz zaliczał do tradycji chrześcijańskiej teologii solarnej. W ceremonii tej cesarz działał jako „christomimetes”, czyli ten, który odgrywa rolę Chrystusa w uroczystościach kościelnych ${ }^{59}$.

Drugi wykład Kantorowicza wygłoszony w ramach sympozjum w Dumbarton Oaks w 1950 roku zatytułowały został Synthronos: God and

56 Kantorowicz, Oriens Augusti - Lever du Roi, s. 150.

57 Kantorowicz, Oriens Augusti-Lever du Roi, s. 151.

58 Kantorowicz, Oriens Augusti-Lever du Roi, s. 151.

59 Kantorowicz, Oriens Augusti - Lever du Roi, s. 151: „The Christian emperor - the supreme God's hyparchos on earth, next to Christ as God's hyparchos in heaven became the christomimetes above all others, that is, the one imitating and impersonating, even ceremoniously staging, Christ, the ruler of the universe. Hence, the imperial solar predications, though historically a survival from the pagan past, or a continuation of it, were henceforth backed up and legitimized by the solar nomenclature of Christ himself'. Kantorowicz twierdzi ponadto, że choć idea oriens augusti pojawiła się dopiero w III stuleciu, to u jej podłoża tkwiły o wiele starsze wyobrażenia epifanii i adventus (s. 132). Oriens uznaje on za synonim epifanii czy adventus, czyli uroczystego zjawienia się władcy (s. 138), rytualnego przybycia do miasta hellenistycznego króla czy rzymskiego cesarza, w osobie którego - jak wierzono - nawiedzał to miasto sam bóg. Idei adventus Kantorowicz poświecił osobne stadium: The 'King's Advent': and the Enigmatic Panels in the Doors of Santa Sabina. 
King as Throne-sherers ${ }^{60}$ i dotyczył wyobrażenia współrządzenia cesarza z bóstwem. Także ten obraz miał pochodzenie wschodnie - m.in. w Egipcie popularne były przedstawienia faraonów dzielących tron wraz z bóstwem opiekuńczym. Spotykamy je również w Biblii. Najsłynniejszym przykładem jest Psalm 109 opisujący moment intronizacji, w ramach której król zajmuje miejsce na tronie YHWH. Obraz króla zasiadającego po prawicy Boga wyrażał przekonanie, że monarcha ma udział we władzy, potędze i godności Boga, że rządzi w imieniu YHWH. Co więcej, w psalmie 109 intronizacja wiąże się z adopcją przez YHWH, w wyniku której król zostaje wyniesiony do rangi Syna Bożego.

Kantorowicz przypomniał, że psalm 109 należał do tych miejsc Starego Testamentu, które były najczęściej cytowane przez chrześcijan ${ }^{61}$. Odniesienia do niego spotykamy m.in. w najstarszym chrześcijańskim wyznaniu wiary oraz w hymnie Gloria. W chrześcijańskiej wykładni psalmu królem zasiadającym po prawicy YHWH jest, rzecz jasna, Chrystus. List do Hebrajczyków stwierdza, że Bóg intronizował Chrystusa w momencie zmartwychwstania (Hbr 1,3; 1,13; 10,12-13; 12,2). Od tego momentu dzieli On z Ojcem tron, władzę i chwałę. Co więcej, Chrystus obiecał męczennikom i zabawionym nagrodę - wspólne zasiadanie na tronie: „Zwycięzcy dam zasiadać wraz ze Mną na moim tronie, jak i Ja zwyciężyłem i zasiadam z mym Ojcem na Jego tronie" (Ap 3,21). Psalm 109 rozumiano zatem

60 Wykład wygłoszony 27 kwietnia 1950 roku w ramach sympozjum ,,The Emperor and the Palace", w: http://www.archive.org/stream/ernstkantorowicz00reel01\#page/ n793/mode/1up (11.01.2021). Wyobrażeniu zasiadania władcy na tronie wspólnie z Dike Kantorowic poświęcił artykuł Synthronos Dikhi („American Journal of Archaeology” 57 (1953) s. 65-70). Sugerował w nim, że motyw ten nie był jedynie przenośnią, lecz władcy istotnie zasiadali na tronach obok posągu Dike. Dodajmy, że intronizacja z psalmu 109 również mogła mieć sens dosłowny: A. Rebić, Znaczenie „, siedzi po prawicy ojca” w Starym Testamencie, „Communio” 7 (1987) s. 13: „Ryt intronizacyjny odbywał się mianowicie w świątyni, gdzie znajdował się tron Jahwe. Podczas intronizacji król zasiadałby więc naprawdę po ,prawicy” tronu Jahwe (Arki Przymierza)”.

61 D.M. Hay (Glory at the Right Hand: Psalm 110 in Early Christianity, Nahville - New York 1973, s. 15) w samym Nowym Testamencie doliczył się trzydziestu trzech cytatów i aluzji. Szerzej na temat psalmu 109, zob. M. Filipiak, Ps 110-Mesjasz: król, kapłan, zwycięzca, w: Mesjasz w biblijnej historii zbawienia, red. S. Lacha, Lublin 1975, s. 225-255. Zob. również: C. Markschies, ,, Sessio ad Dexteram ”. Bemerkungen zu einem altchristlichen Bekenntnismotiv in der christologischen Diskussion der altkirchlichen Theologen, w: Le Trône de Dieu, red. M. Philonenko, Tübingen 1993, s. 252-317, który dostrzegł wkład Kantorowicza w badania motywu synthronos (s. 261 263), zwłaszcza w studium: E.H. Kantorowicz, The Quinity of Winchester, „The Art Bulletin” 2 (1947) s. 73-85. 
jako potwierdzenie, że chrześcijański władca dzieli tron z Chrystusem. Jak Chrystus zasiada po prawicy Ojca i uczestniczy w Jego władzy, tak bazyleus ma udział we władzy Chrystusa.

W psalmie 109 królewskie dzielenie tronu z YHWH wiąże się z obietnicą przyszłego zwycięstwa: „Siądź po mojej prawicy, aż Twych wrogów położę jako podnóżek pod Twoje stopy". Intronizacja nowego króla łączyła się zatem $\mathrm{z}$ obrazem triumfu wizualizowanego jako deptanie wrogów. Obraz powalonego nieprzyjaciela czy barbarzyńcy, na którego głowie lub karku triumfator stawiał stopę, należał do kanonicznych rzymskich póz zwycięstwa. Krótki zarys problemu deptania karku (calcatio colli) Kantorowicz zawarł w kolejnym bizantyńskim wykładzie zatytułowanym Roman Coins and Christian Rites ${ }^{62}$. Swój wywód zaczął od obserwacji, że w epoce późnocesarskiej deptanie karku stało się częstym tematem rzymskich monet. Ukazywały one cesarza lub bóstwo - np. Sol Invictus - kopiące lub stawiające stopę na związanym lub powalonym jeńcu.

Wizerunki te miały związek z rzymską teologią zwycięstwa ${ }^{63}$. Należy pamiętać, że rzymski cesarz był przede wszystkim wodzem, a militarne zwycięstwo należało do najważniejszych czynników legitymizacji jego władzy. Zwycięstwo gloryfikowano nie tylko widokiem triumfatora, ale również pokazywaniem pokonanych. Stąd obecność siedzących na ziemi skutych jeńców, klęczących i błagających o litość barbarzyńców, a także tratowanych czy kopanych wrogów - oni również symbolizowali moc i chwałę zwycięskiego wodza. W bogatym repertuarze gestów rzymskiej propagandy zwycięstwa deptanie karku zajmowało miejsce uprzywilejowane ${ }^{64}$.

62 E. Kantorowicz, Roman Coins and Christian rites, w: www.archive.org/stream/ ernstkantorowicz00reel01\#page/n1057/mode/1up (11.01.2021). Wykład składał się dwóch części. Pierwsza o wyobrażeniu concordia została rozwinięta i wygłoszona oddzielnie w 1958 roku w ramach sympozjum „The Dumbarton Oaks Collection. Studies in Byzantine Art” a następnie opublikowana jako On the Golden Marriage Belt and the Marriage Rings of the Dumbarton Oaks Collection. Druga, nieopublikowana część wykładu dotyczyła motywu calcatio.

63 Zob. J. Gagé, La théologie de la victoire impériale, „Revue historique” 171 (1933) s. 1-43; J. Fears, The Theology of Victory at Rome: Approaches and Problems, ANRW 2.17.2, Berlin - New York 1981, s. 736-826; D. Brodka, ,,Teologia zwycięstwa” cesarzy chrześcijańskich a „Historia ecclesiastica” Rufina z Akwilei, „Meander” 54 (1999) s. 457-464; K. Balbuza, Triumfator. Triumf $i$ ideologia zwycięstwa $w$ starożytnym Rzymie epoki cesar-

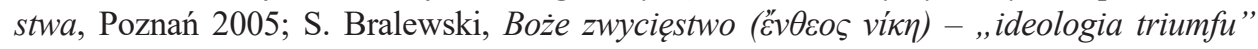
w „Historii kościelnej” Euzebiusza z Cezarei, „Vox Patrum” 63 (2015) s. 331-351.

64 Na temat calcatio, zob. m.in. G. Rodenwaldt, Der Belgrader Kameo, „Jahrbuch des Deutschen Archäologischen Instituts" 37 (1922) s. 17-38; F. Gössmann, Scabellum pedum tuorum, „Divinitas” 11 (1967) s. 30-53; P.G.J. Post, „,Conculcabis leonem...”. 
Kantorowicz zauważył, że motyw ceremonialnego poniżania wroga popularny był również w Cesarstwie Bizantyńskim. Calcatio colli od V wieku weszło do obchodów bizantyńskiego triumfu, stanowiąc składnik „,esarskiej liturgii”. Tytułem przykładu, historyk przytaczał, zrelacjonowane przez pseudo-Kodinosa (De ceremoniis II 19) obchody triumfu z 956 roku odprawione z okazji pochwycenia arabskiego dowódcy. Podczas uroczystości pojmany wódz padł przed bazyleusem na twarz, a cesarz postawił na nim stopę, prostrator zaś przystawił do szyi leżącego grot cesarskiej włóczni ${ }^{65}$. Calcatio colli symbolizowało tu całkowite zwycięstwo i pełne podporządkowywanie wroga. Brutalność tej sceny - niczym skopiowanej z rzymskich monet - zdaje się sytuować ją na antypodach chrześcijańskiej wrażliwości. A jednak dla Kantorowicza bizantyńska ceremonia nie nawiązywała do rzymskiej tradycji militarnej. Towarzyszące ceremonii śpiewy psalmów i aklamacje wskazywały jednoznacznie, że scenę tę należało sytuować w kontekście biblijnym.

W psalmie 109 król, zasiadający na tronie po prawicy YHWH, był zwycięzcą. W jego chrześcijańskiej interpretacji zwycięstwo to odnoszono do Chrystusa, który na krzyżu pokonał grzech i śmierć. Jako victor Chrystus przejął wiele formuł ikonograficznych wywodzących się z cesarskiej sztuki triumfalnej, w tym także deptanie wrogów. Jako niebiański władca, w scenach zmartwychwstania i zstąpienia do otchłani, Chrystus stawiał stopę na karku personifikacji sił ciemności.

Kantorowicz konkludował, że bizantyńskie deptanie arabskiego wodza było rodzajem biblijnego tableau vivant inscenizującym werset psalmu 90: „Będziesz stąpał po wężach i żmijach, a lwa i smoka będziesz mógł podeptać”. W inscenizacji tej bizantyński bazyleus wcielał się w rolę Jezusa jako zwycięzcy. Bazyleus, mając udział w Jego władzy, miał również udział w Jego triumfie nad siłami zła ${ }^{66}$. Tak jak dla Mesjasza, tak dla Jego cesarskiego wikariusza wrogowie byli podnóżkiem stóp jego.

Some iconographic and iconologic notes on an early-Christian terracotta-lamp with an Anastasis-scene, „Rivista di Archeologia Cristiana” 1-2 (1982) s. 147-176; A. Passoni dell'Acqua, L'immagine del'calpestare dall'Antico Testamento ai Padrid ella Chiesa, „Anagennesis” 4 (1986) s. 63-129; Ch.W. Malone, Violence on Roman Imperial Coinage, „Journal of the Numismatic Association of Australia” 20 (2009-2010) s. 58-72.

65 Na temat bizantyńskiego ceremoniału triumfu: M. McCormick, Eternal Victory: Triumphal Rulership in Late Antiquity, Byzantium and the Early Medieval West, Cambridge 1990, s. 189-230; M. Pietranik, Celebracja cesarskich zwycięstw militarnych w późnym Bizancjum w świetle kroniki Jerzego Akropolitesa, ,Wieki Stare i Nowe” 13 (2018) s. 33-51.

${ }_{66}$ W swym wykładzie Kantorowicz wspomina o przedstawieniach scen calcatio, w których depczącymi byli rzymscy papieże. I. Hekloz twierdzi, że również w tym wypadku motyw ten należy rozumieć nie w kategoriach imitatio imperii, ile jako imitatio Christi. 
Na koniec wspomnę krótko artykuł The Baptism of the Apostles ogłoszony na łamach „Dumbarton Oaks Papers” w 1956 roku $^{67}$. Nominalnie Kantorowicz poruszył w nim kwestię chrztu Apostołów, w istocie zajął się tradycją egzegetyczną sceny obmycia nóg z Ewangelii Św. Jana. Dominująca wykładnia w akcie lavatio pedum widzi wyraz pokory i posługi charakterystyczny dla chrześcijańskiej koncepcji władzy, której istotą jest służba. Czynność, należącą do obowiązków sługi czy niewolnika, zostaje wykonana przez Chrystusa. Kantorowicz zrekonstruował istnienie innej wykładni, w myśl której gest obmycia nóg był rozumiany jako oczyszczenie i uświęcenie ${ }^{68}$. Koronne świadectwo istnienia tej tradycji znajdujemy u św. Ambrożego, który w De sacramentis (III 5) mówi o pedilevium jako o misterium czy wręcz odrębnym sakramencie ${ }^{69}$. W tym kontekście słowa Jezusa skierowane do Piotra „Jeśli cię nie umyję, nie masz części ze mną" (J 13,8) wyrażają legitymizujący sens aktu, który zapewnia partycypację we władzy Chrystusa. Stąd moment ten był niekiedy rozumiany jako chrzest Apostołów - ustanowienie ich władzy.

Już na wstępie artykułu Kantorowicz przypominał, że w Wielki Czwartek do obowiązków bazyleusa należało obmywanie nóg dwunastu biedakom $^{70}$. Albowiem ,bizantyński cesarz był uważany za najbardziej re-

Papież, jako wikariusz Chrystusowy, ma udział w triumfie Chrystusa. Por. I. Hekloz, Gli eredi di Costantino. Il papato, il Lateran e la propaganda visiva nel XII secolo, Roma 2000, s. 115-122.

67 E.H. Kantorowicz, The Baptism of the Apostles, „Dumbarton Oaks Papers” 9-10 (1956) s. 204-251. Artykuł na podstawie referatu wygłoszonego w kwietniu 1954 roku w ramch „Symposium on Byzantine Liturgy and Music” w Dumbarton Oaks.

68 Na temat interpretacji pedilavium, zob. m.in. P. Wiśniewski, Dzieje wielkoczwartkowego obrzędu ,, mandatum”, „Liturgia Sacra” 1 (2004) s. 75-93; A. Kubiś, Interpretacja pokutna Janowego opisu obmycia stóp uczniom przez Jezusa, „The Biblical Annals” 3 (2018) s. 379-420.

69 Ambrosius, De mysteriis III 5, tł. L. Gładyszewski - S. Pieszczoch, Św. Ambroży, Wybór pism dogmatycznych, Poznań - Warszawa - Lublin 1970: „Wiemy, że Kościół rzymski, którego przykład i wzór we wszystkim naśladujemy, nie ma tego obrzędu mycia nóg.[...] Ale przecież czym innym jest przejaw pokory, a czym innym - akt uświęcenia. Tutaj, jak słyszysz, jest i tajemnica, i uświęcenie: [...] Myjesz więc nogi, aby zmyć truciznę węża".

70 E.H. Kantorowicz, The Baptism of the Apostles, „Dumbarton Oaks Papers” 9-10 (1956) s. 205. Ilustracji wielkoczwartkowego ceremoniału bizantyńskiego Kantorowicz dopatrzył się w trzynastowiecznym koptyjskim ewangeliarzu z Bibliothèque Nationale w Paryżu. W odróżnieniu od dominującego typu ikonograficznego, w którym św. Piotr siedzi, a Chrystus pochyla się lub wręcz klęczy przed Piotrem, w tym przedstawieniu Chrystus siedzi na okazałym krześle przed stojącym Piotrem (Kantorowicz, The Baptism of the Apostles, s. 223-224 
alistyczny żywy obraz Chrystusa. W związku z tym wiernie reprezentował Pana przede wszystkim w największe święta kościelne. W Niedzielę Palmową, podczas ceremonii peripatos, dokonywał wjazdu do Jerozolimy ${ }^{71}$. W Wielki Czwartek odwiedzał szpitale, a następnie, obmywał nogi dwunastu biedakom. W Niedzielę Wielkanocną inscenizował zmartwychwstanie, w prawej dłoni trzymając krzyż symbolizujący anastasis, w lewej zaś - sakiewkę z ziemią. W podobny sposób do jego obowiązków należało reprezentowanie Pana w dniu Epifanii ${ }^{72}$.

\section{Podsumowanie}

Poszukując w bizantynologicznych studiach Kantorowicza stanowiska w kwestii teologii politycznej, nie można oczekiwać teoretycznego wywodu, nie znajdzie się go bowiem nawet w studium ze średniowiecznej teologii politycznej, jakim są Dwa ciała króla. Cechą metodologii niemieckiego historyka była nieufność wobec nadmiernych generalizacji i teoretyzowania - zarzut ten expressis verbis stawiał on niektórym pracom z zakresu historii idei ${ }^{73}$. On sam wolał analizy szczegółowych tekstów, wizerunków i rytuałów, z których wynikały ogólniejsze konkluzje i których wyciągnięcie pozostawiał czytelnikom ${ }^{74}$. W wypadku teologii politycznej w Bizancjum Kantorowicz oparł się na analizach świąt kościelnych i uroczystości, w których uczestniczył bazyleus ${ }^{75}$. Pomimo odmienności kontekstów oraz

oraz il. 45). Szerzej na temat przedstawień pedilavium, zob. H. Giess, Die Darstellung der Fusswaschung Christi in der Kunstwerken des 4-12 Jahrhunderts, Roma 1962, która wspomina interpretację Kantorowicza (Die Darstellung der Fusswaschung Christi, s. 100).

71 W 1944 roku Kantorowicz pisał (The „,King 's Advent”, s. 230): ,on Palm Sunday [...] he [basyleus] celebrated the day with a great procession, Peripatos, within the palace where he himself would stage the Lord's Entry into Jerusalem after his own imperial fashion".

72 Kantorowicz, Epiphany and Byzantine Coronation, s. 19.

73 W przedmowie do The King's Two Bodies (s. IX, t1. polskie, s. XXXI) Kantorowicz dostrzega ,certain dangers customary with some all-too-sweeping and ambitious studies in the history of ideas: loss of control over topics, material, and facts; vagueness of language and argument; unsubstantiated generalizations; and lack of tension resulting from tedious repetitions".

74 Owo skupienie na szczególe oceniano niekiedy jako ,przesadną miniaturyzację”. Zob. Lerner, Ernst Kantorowicz, s. 362. Była to jednak świadomie przyjęta zasada metodologiczna. Kantorowicz znał i podzielał dewizę Aby’ego Warburga: „Bóg tkwi w szczególe”.

75 Biograf Kantorowicza podaje, że w czasie pracy na uniwersytecie w Berkeley historyk czytał ze studentami Księge o Ceremoniach Konstantyna VII Porfirogenety, a tak- 
różnorodności opisywanych rytuałów stale powracał jeden motyw: cesarz jako zastępca Chrystusa. Motyw ten wywodził się z przekonania, że władza polityczna bazyleusa pochodzi od Chrystusa i jest sprawowana w Jego imieniu. Przekonanie to było zgodne z podstawowym aksjomatem hellenistycznych teorii politycznych głoszącym, że władca jest manifestacją boskości: bogiem przez naśladownictwo lub bogiem per gratiam $^{76}$.

Kantorowicz nie miał wątpliwości, że bizantyńskie rozumienie władzy oddziaływało również na Zachodzie. W jednej ze swoich prac pisał:

Dzisiejszy historyk nie może zignorować Bizancjum niczym jakiejś intelektualnej dygresji. Nie wykluczy ze swojej opowieści Europy znajdującej się po drugiej stronie Adriatyku. Nie wytyczy granicy ani nie ustanowi intelektualnej kontroli celnej w Wenecji. Nie pominie istnienia Europy południowo-wschodniej [...]. Nie da się bowiem tak po prostu wymazać z pamięci faktu, że stworzone przez Konstantyna Cesarstwo-Kościół, owa fuzja rzymskiego Cesarstwa z chrześcijańskim Kościołem, służyła - z pewnymi przeróbkami czy zafałszowaniami - za podstawę teorii i aktywności politycznej w okresie całego średniowiecza, tj. do ok. 1300 roku [...]. W istocie średniowieczny świat Zachodu nie powołał do istnienia żadnego nowego politycznego rozwiązania, które mogłoby przewyższyć, ulepszyć czy zastąpić rozwiązanie Konstantyna. Karolińskie czy ottońskie Cesarstwo-Kościół, podobnie jak Gregoriański Kościół-Imperium, to jedynie parafrazy konstantyńskiej melodii ${ }^{77}$.

\section{Imperial Epiphany. Ernst H. Kantorowicz as a Scholar of Byzantine Political Theology}

(summary)

Ernst Hartwig Kantorowicz is not famous for being a Byzantinist, nevertheless he has dedicated a great deal of his scholarly attention to the Byzantine East. In the 1940's, while teaching at Berkeley University, he regularly attended conferences with lectures on Eastern topics. In 1950's, he inaugurated his lifelong collaboration with the Byzantine

że Relatio de legatione Constantinopolitana Liutpranda z Cremony. Zob. Lerner, Ernst Kantorowicz, s. 275.

76 Por. Kantorowicz, Deus per naturam, deus per gratiam.

77 E.H. Kantorowicz, The Problem of Medieval World Unity, „Annual Report of the American Historical Association” 3 (1944) s. 32 (tł. polskie, R. Pawlik, „Kronos” 2 (2019) s.193-194). 
centre at Dumbarton Oaks. In the last years of his life, he worked on a book project which was to collect his works on byzantine political theology. The book was conceived as a ,sequel” to the „King's Two Bodies”, the culmination of his research on medieval political theology in the Western world. Death prevented him from the completion of the Byzantine project, but unpublished conference lectures as well as three studies published in the journal „Dubarton Oaks Papers” allow us some insight into the Kantorowicz's vision. In the present paper I try to reconstruct Kantorowicz's contribution to the study of political theology, or rather political Christology of the Byzantine Empire.

Keywords: Ernst H. Kantorowicz; Byzantium; political theology; political Christology; Christomimetes; prokypsis

\section{Cesarska epifania. Ernst H. Kantorowicz jako badacz bizantyńskiej teologii politycznej}

(streszczenie)

Kantorowicz nie jest znany jako badacz Bizantyjskiego Wschodu. Faktem jest jednak, że przez większą część swej naukowej kariery intensywnie zajmował się Bizancjum. Od 1940 roku, czyli od początku swej pracy na Uniwersytecie w Berkeley, regularnie brał udział w konferencjach bizantynologicznych, od 1950 roku w tych organizowanych przez ośrodek Dumbarton Oaks. W ostatnich latach życia przygotowywał do druku książkę zbierającą swe dokonania na tym polu. Ich wspólnym mianownikiem miała być teologia polityczna w cesarstwie bizantyjskim. Książkę tę postrzegał jako kontynuację „Dwóch ciał króla", które stanowiły zwieńczenie jego badań nad teologią polityczną w świecie zachodnim. Śmierć uniemożliwiła dokończenie tego projektu, jednak niepublikowane wykłady konferencyjne oraz studia ogłoszone na łamach „Dubarton Oaks Papers” pozwalają wyrobić sobie pojęcie na temat Kantorowiczowego ujęcia teologii politycznej w Bizancjum. W artykule podejmuję próbę wstępnej rekonstrukcji wkładu Kantorowicza w rozumieniu teologii politycznej, czy raczej politycznej chrystologii, w Cesarstwie Bizantyjskim.

Słowa kluczowe: Ernst H. Kantorowicz; Bizancjum; teologia polityczna; polityczna chrystologia; Christomimetes; prokypsis

\section{Bibliografia}

Arystotelis, Metaphysica, w: Aristotelis Metaphysica, ed. W Jaeger, Oxford 1957, t1. K. Leśniak, Arystoteles, Metafizyka, Warszawa 1984.

Arystotelis, De mundo, w: Aristotelis qui fertur libellus De Mundo, ed. W.L. Lorimer, Paris 1933, tł. A. Paciorek, Arystoteles, Meteorologika, O świecie, Warszawa 1982. Augustinus, De civitate Dei, Corpus Christianorum, Series Latina XLVII/XIV, t. 1-2, ed. B. Dombart - A. Kalb, Turnhout 1955, tł. W. Kornatowski, Augustyn, O państwie Bożym: przeciw poganom ksiąg XXII, Warszawa 1977. 
Bartyzel J., ,Nie-polityczna teologia” Erika Petersona, w: Chrześcijaństwo i Europa wobec sekularyzacji. Religia w niemieckiej myśli politycznej XX wieku, red. A. Wielomski - Ł. Święcicki, Warszawa 2018, s. 93-113.

Balbuza K., Triumfator. Triumf i ideologia zwycięstwa $w$ starożytnym Rzymie epoki cesarstwa, Poznań 2005.

Böckenförde E.-W., Teoria polityki a teologia polityczna. Uwagi na temat ich wzajemnego stosunku, tł. M. Kurkowska, ,Teologia Polityczna” 3 (2005-2006) s. 301-309.

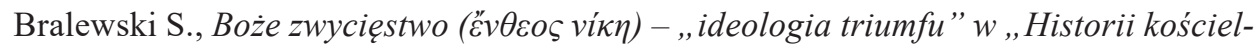
nej” Euzebiusza z Cezarei, „Vox Patrum” 63 (2015) s. 331-351.

Brodka, D., ,, Teologia zwycięstwa” cesarzy chrześcijańskich a ,Historia ecclesiastica” Rufina z Akwilei, „Meander” 54 (1999) s. 457-464.

Cantor N., The Inventing Middle Ages, New York 1991.

Hay D.M., Glory at the Right Hand. Psalm 110 in Early Christianity, Nashville - New York 1973.

Fears J., The Theology of Victory at. Rome: Approaches and Problems, ANRW 2.17.2, Berlin - New York 1981.

Hekloz I., Gli eredi di Costantino. Il papato, il Lateran e la propaganda visiva nel XII secolo, Roma 2000.

Filipiak M., Ps 110 - Mesjasz: król, kapłan, zwycięzca, w: Mesjasz w biblijnej historii zbawienia, red. S. Łach, Lublin 1975, s. 225-255.

Giess H., Die Darstellung der Fusswaschung Christi in der Kunstwerken des 4-12 Jahrhunderts, Roma 1962.

Gagé J., La théologie de la victoire impériale, „Revue historique” 171 (1933) s. 1-43.

Geréby G., Carl Schmitt and Erik Peterson on the Problem of Political Theology: A Footnote to Kantorowicz, w: Monotheistic Kingship: The Medieval Variants, Monotheistic Kingship: The Medieval Variants, red. J. Bak - A. Al-Azmeh, Budapest 2004, s. 31-61.

Giesey R.E., Ernst H. Kantorowicz Scholarly Triumphs and Academic Travails in Weimar Germany and the United States, „Yearbook of the Leo Baeck Institute” 30 (1985) s. 191-202.

Gössmann F., Scabellum pedum tuorum, „Divinitas” 11 (1967) s. 30-53.

Herrero M., On Political Theology: The Hidden Dialogue between C. Schmitt and Ernst H. Kantorowicz in The King's Two Bodies, „History of European Ideas” 41 (2015) s. 1164-1177.

Jeffreys M., The Comnenian Prokypsis, „Parergon” 5 (1987) s. 38-53.

Kahn V., Political Theology and Fiction in The King's Two Bodies, „Representations” 1 (2009) s. 77-101.

Kantorowicz E.H., The Baptism of the Apostles, „Dumbarton Oaks Papers” 9-10 (1956) s. 204-251.

Kantorowicz E.H., Deus per naturam, deus per gratiam, A Note on Mediaeval Political Theology, „Harvard Theological Review” 45 (1952) s. 253-77. 
Kantorowicz E.H., Fryderyk II (1194-1250), tł. G. Smółka, Oświęcim 2015.

Kantorowicz E.H., The Fundamental Issue: Documents and Marginal Notes on the University of California Loyalty Oath, San Francisco 1950 (Wolność akademicka jako kwestia fundamentalna, tł. K. Rychter, „Kronos” 3 (2016), s. 11-32).

Kantorowicz E.H., Epiphany and Byzantine Coronation (niepublikowany wykład).

Kantorowicz E.H., ,Feudalism” in the Byzantine Empire, w: Feudalism in History, red. R. Coulborn, Princeton 1956, s. 151-166.

Kantorowicz E.H., The King's Two Bodies. A Study in Medieval Political Theology, Princeton 1957 (Dwa ciała króla. Studium z teologii politycznej średniowiecza, tł. M. Michalski - A. Krawiec, Warszawa 2007).

Kantorowicz E.H., The „King's Advent”: And The Enigmatic Panels in the Doors of Santa Sabina, „The Art Bulletin” 4 (1944) s. 207-231.

Kantorowicz E.H., Laudes Regiae: A Study in Liturgical Acclamations and Medieval Ruler Worship, Berkeley - Los Angeles 1946.

Kantorowicz E.H., Mysteries of State. An Absolutist Concept and its Late. Mediaeval Origins, „Harvard Theological Review” 48 (1955) s. 65-91.

Kantorowicz E.H., On the Golden Marriage Belt and the Marriage Rings of the Dumbarton Oaks Collection, „Dumbarton Oaks Papers” 14 (1960) s. 2-16.

Kantorowicz E.H., Oriens Augusti - Lever du Roi, „Dumbarton Oaks Papers” 17 (1963) s. 119-177.

Kantorowicz E.H., The Problem of Medieval World Unity, „Annual Report of the American Historical Association" 3 (1944) s. 31-37.

Kantorowicz E.H., The Quinity of Winchester, „The Art Bulletin” 2 (1947) s. 73-85.

Kantorowicz E.H., Roman Coins and Christian Rites (niepublikowany wykład).

Kantorowicz E.H., Synthronos Dikhi, „American Journal of Archaeology” 57 (1953) s. $65-70$.

Kantorowicz E.H., Synthronos: Throne Sharing with the Deity (niepublikowany wykład).

Kubiś A., Interpretacja pokutna Janowego opisu obmycia stóp uczniom przez Jezusa, „The Biblical Annals” 3 (2018) s. 379-420.

Lerner R.E., Ernst Kantorowicz: A Life, Princeton 2017.

Lerner R.E., Kantorowicz and Continuity, w: Ernst Kantorowicz. Erträge der Doppeltagung Institute for Advanced Study, Princeton, Johann Wolfgang Goethe-Universität, Frankfurt, red. R. Benson - J. Fried, Stuttgart 1997, s. 104-123.

Lieberg G., The Theologia Tripartita as an Intellectual Model in Antiquity, w: Essays in Memory of Karl Kerényi, red. E.C. Polomé, Washington 1984, s. 91-115.

McCormick M., Eternal Victory: Triumphal Rulership in Late Antiquity, Byzantium and the Early Medieval West, Cambridge 1990.

Macrides R., Pałac późnobizantyński i jego ceremoniał, tł. M. Biedrawa-Raczyńska, „Przegląd Nauk Historycznych” 1 (2014) s. 5-22.

Maguire H., Andre Grabar (1896-1990), „Dumbarton Oaks Papers” 95 (1991) s. xii-xv. 
Maier H., Erik Peterson i problem teologii politycznej, tł. K. Marulewska, „44. Magazyn Apokaliptyczny" 8 (2016) s. 201-220.

Malkiel Y., Ernst H. Kantorowicz, „Romance Philology” 1 (1964) s. 1-15.

Malone Ch.W., Violence on Roman Imperial Coinage, ,Journal of the Numismatic Association of Australia" 20 (2009-2010) s. 58-72.

Markschies C., ,, Sessio ad Dexteram”. Bemerkungen zu einem altchristlichen Bekenntnismotiv in der christologischen Diskussion der altkirchlichen Theologen, w: Le Trône de Dieu, red. M. Philonenko, Tübingen 1993, s. 252-317.

Mehring R., Nemo contra theologum nisi theologus ipse. Odpowiedź Carla Schmitta udzielona Erikowi Petersonowi, tł. K. Marulewska, „44. Magazyn Apokaliptyczny” 7 (2013) s. 114-132.

Meier H., Czym jest teologia polityczna? Wstepne uwagi na temat kontrowersyjnego pojęcia, tł. M. Kurkowska, „Teologia Polityczna” 1 (2003-2004) s. 177-184.

Mythen, Körper, Bilder: Ernst Kantorowicz zwischen Historismus, Emigration und Erneuerung der Geisteswissenschaften, red. L. Burkart, Göttingen 2015.

Nicoletti M., Nowe spojrzenie na polemikę: Erik Peterson-Carl Schmitt, tł. T. Myśków - K. Marulewska, „44. Magazyn Apokaliptyczny” 4 (2012) s. 44-72.

Nichtweiss B., Apokaliptyczne teorie konstytucji. Carl Schmitt w kontekście teologii Erika Petersona, tł. K. Marulewska, „44. Magazyn Apokaliptyczny” 5 (2012) s. 179-216.

Passoni dell'Acqua A., L'immagine del'calpestare dall'Antico Testamento ai Padridella Chiesa, „Anagennesis” 4 (1986) s. 63-129.

Pawlik R., Le teologie politiche medievali e le loro ripercussioni novecentesche: Ernst Kantorowicz in discussione con Carl Schmitt e Erik Peterson, w: Ernst Kantorowicz (1895-1963). Storia politica come scienza culturale, red. T. Frank - D. Rando, Pavia 2015, s. 19-43.

Peterson E., Die Einholung des Kyrios, „Zeitschrift für Systematische Theologie” 7 (1930) s. 682-702.

Peterson E., Heis Theos. Epigraphische, Formgeschichtliche und Religionsgeschichtliche Untersuchungen, zur antiken ,Ein-Gott”-Akklamation, Göttingen 1926.

Peterson E., Die neueste Entwicklung der protestantischen Kirche in Deutschland, „Hochland” 31 (1933/34) s. 64-79 i 144-160 (przedruk w: E. Peterson, Theologie und Theologen, red. B. Nichtwei, Ausgewählte Schriften 9/1, Würzburg 2009, s. 610-645).

Peterson E., Der Monotheismus als politisches. Ein Beitrag zur Geschichte der politischen Theologie im Imperium Romanum, Leipzig 1935 (przedruk w: E. Peterson, Theologische Traktate, München 1951, s. 45-147; Monoteizm jako problem polityczny. Przyczynek do dziejów teologii politycznej w imperium romanum, tł. J. Duraj „Res Publica Nowa” 20 (2012) s. 39-61].

Pépin J., La „, Théologie tripartite” de Varron. Essai de reconstitution et recherche des sources, „Revue des études augustiniennes” 2 (1956) s. 265-294. 
Pietranik M., Celebracja cesarskich zwycięstw militarnych w późnym Bizancjum w świetle kroniki Jerzego Akropolitesa, „Wieki Stare i Nowe” 13 (2018) s. 33-51.

Post P.G.J., „Conculcabis leonem...”: Some iconographic and iconologic notes on anearly-Christian terracotta-lamp with an Anastasis-scene, ,Rivista di Archeologia Cristiana" 1-2 (1982) s. 147-176.

Rebić A., Znaczenie „siedzi po prawicy ojca” w Starym Testamencie, „Communio” 7 (1987) s. 10-13.

Rodenwaldt R., Der Belgrader Kameo, „Jahrbuch des Deutschen Archäologischen Instituts" 37 (1922) s. 17-38.

Rust J., Political Theologies of the Corpus Mysticum: Schmitt, Kantorowicz, and de Lubac, w: Political Theology and Early Modernity, red. G. Hammill - J. Reinhard Lupton, Chicago 2012, s. 102-123.

Rüpke J., Varro's tria genera theologiae: religious thinking in the late Republic, „Ordia Prima" 4 (2005) s. 107-129.

Scattola M., Teologia polityczna, t1. P. Borowski, Warszawa 2007.

Schmitt C., Politische Theologie - Vier Kapitel zur Lehre von der Souveränität, Berlin 1922 (Teologia polityczna. Cztery rozdziaty poświęcone nauce o suwerenności, t1. M. Cichocki, w: Teologia polityczna i inne pisma, Kraków 2000, s. 33-83).

Schmitt C., Politische Theologie II. Die Legende von der Erledigung jeder politischen Theologie, Berlin 1970 (Teologia polityczna 2. Legenda o wykluczeniu wszelkiej politycznej teologii, tł. B. Baran, Warszawa 2014).

Ševčenko I., Ernst H. Kantorowicz (1895-1963) on Late Antiquity and Byzantium w: Ernst Kantorowicz. Erträge der Doppeltagung Institute for Advanced Study, Princeton, Johann Wolfgang Goethe-Universität, Frankfurt, red. R. Benson - J. Fried, Stuttgart 1997, s. 274-287.

Sureau D., Teologie polityczne XX wieku, tł. M. Grądzka-Holvoote, „Christianitas” 45-46 (2011) s. 111-140.

Weber D., Deus per naturam, deus per gratiam. Une note sur la theologie politique médiévale. Présentation, „Les Etudes philosophiques” 1 (2011) s. 105-108.

Wiśniewski P., Dzieje wielkoczwartkowego obrzędu ,,mandatum”, „Liturgia Sacra ” 1 (2004) s. 75-93.

Woźniak R.J., Ontologia trynitarna i polityka. Uwagi na marginesie debaty Erika Petersona i Carla Schmitta o politycznej teologii, w: Rozwój dogmatu trynitarnego. Perspektywa historiozbawcza, red. A. Baron, Kraków 2015, s. 301-318. 